\title{
Antioxidant capacity of extracts and isolated compounds from Stryphnodendron obovatum Benth.
}

\author{
Analice Martins Daleffi Zocoler ${ }^{1}$, Andréia Cristina Conegero Sanches ${ }^{2}$, Ingrid Albrecht ${ }^{1}$, João \\ Carlos Palazzo de Mello ${ }^{1} *$
}

${ }^{1}$ Department of Pharmacy and Pharmacology, University of Maringá, ${ }^{2}$ Center of Medical Sciences and Pharmacy, State University of Western Paraná

\begin{abstract}
The extract from stem bark of Stryphnodendron obovatum Benth. was chromatographed on a Sephadex ${ }^{\circledR}$ LH-20 column, and yielded nine compounds: gallic acid (GA), p-hydroxybenzoic acid (PHB), gallocatechin (GC), epigallocatechin (EPG), 4'-O-methylgallocatechin (MGC), epigallocatechin$(4 \beta \rightarrow 8)$-epigallocatechin (EPEP), epigallocatechin-( $4 \beta \rightarrow 8)$-gallocatechin (EPGC), robinetinidol$(4 \alpha \rightarrow 8)$-gallocatechin (ROGC) and robinetinidol- $(4 \beta \rightarrow 8)$-epigallocatechin (ROEP). Evaluation of the antioxidant capacity in vitro by the methods of DPPH free radical $\left(\mathrm{IC}_{50} ; \mu \mathrm{g} / \mathrm{mL}\right)$ and reduction of the phosphomolybdenum complex (RAC) gave the following results, respectively: crude extract 4.52 and 0.8242 ; ethyl-acetate fraction 4.04 and 0.9537 ; aqueous fraction 5.58 and 0.9275 . The crude extract and ethyl-acetate fraction were shown to possess an antioxidant capacity comparable to that of vitamin C (4.93 and 1.0). The values obtained by the DPPH free-radical method for the isolated compounds were $\mathrm{IC}_{50}(\mu \mathrm{M}): \mathrm{GA}=8.89 ; \mathrm{PHB}=10.12 ; \mathrm{GC}=16.46 ; \mathrm{EPG}=13.20 ; \mathrm{MGC}=21.00 ; \mathrm{EPEP}=6.89 ; \mathrm{EPGC}=4.91$; ROGC $=7.78$ and $\mathrm{ROEP}=6.20$. Vitamin $\mathrm{C}$ and trolox showed 30.11 and 30.10 , respectively. Dimers showed greater activity in scavenging free radicals, possibly related to the number of hydroxyls. However, compounds without a hydroxyl at position 5 of the A-ring (5-deoxy-proanthocyanidins) did not change the antioxidant activity of the DPPH free radical, as evaluated here for the first time. Among the monomers, there appeared to be a direct relationship in scavenging of free radicals because of the stereochemistry of the compounds. The presence of a methyl radical on the B-ring significantly reduced the scavenging of free radicals of gallocatechin. All compounds showed greater scavenging of radicals than vitamin C and trolox, and these two compounds showed no significant difference from each other.
\end{abstract}

Uniterms: Stryphnodendron obovatum. Antioxidant capacity. Condensed tannins. DPPH free radical. Phosphomolybdenum complex.

O extrato das cascas de Stryphnodendron obovatum submetido à cromatografia em coluna, Sephadex ${ }^{\circledR}$ LH20, forneceu nove substâncias: ácido gálico (GA), ácido p-hidróxibenzóico (PHB), galocatequina (GC), epigalocatequina (EPG), 4'-O-metilgalocatequina (MGC), epigalocatequina- $(4 \beta \rightarrow 8)$-epigalocatequina (EPEP), epigalocatequina- $(4 \beta \rightarrow 8)$-galocatequina (EPGC), robinetinidol- $(4 \alpha \rightarrow 8)$-galocatequina (ROGC) e robinetinidol- $(4 \beta \rightarrow 8)$-epigalocatequina (ROEP). A capacidade antioxidante in vitro pelos métodos do radical livre DPPH $\left(\mathrm{IC}_{50} ; \mu \mathrm{g} / \mathrm{mL}\right.$ ) e do complexo fosfomolibdênio (CAR) apresentou os seguintes resultados, respectivamente: extrato bruto 4,52 e 0,8242; fração acetato de etila 4,04 e 0,9537 e fração aquosa 5,58 e 0,9275 demonstrando possuírem capacidade antioxidante quando comparados com vitamina $\mathrm{C} 4,93$ e 1,0. Os valores obtidos pelo método do radical livre DPPH com as substâncias isoladas foram: $\mathrm{IC}_{50}(\mu \mathrm{M}): \mathrm{GA}=8,89 ; \mathrm{PHB}=10,12 ; \mathrm{GC}=16,46 ; \mathrm{EPG}=13,20 ; \mathrm{MGC}=21,00 ; \mathrm{EPEP}=6,89$; $\mathrm{EPGC}=4,91$; $\mathrm{ROGC}=7,78$ e $\mathrm{ROEP}=6,20$. Vitamina $\mathrm{C}$ e trolox mostraram valores de 30,11 e 30,10, respectivamente. Os dímeros mostraram maior atividade no sequestro de radicais livres, possivelmente relacionada com o número de hidroxilas. No entanto, substâncias com ausência de hidroxila na posição 5 do anel A (5-desoxi-proantocianidinas) não alteraram o poder antioxidante frente ao radical livre DPPH,

*Correspondence: Departamento de Farmácia e Farmacologia. Universidade Estadual de Maringá, Avenida Colombo, 5790, Zona 7, BR-87020-900, Maringá, PR, Brazil. Phone/Fax: +55-44-3261-4999. E-mail: mello@uem.br 
tendo sido avaliadas aqui pela primeira vez. Entre os monômeros, parece haver uma relação direta com a estereoquímica. A presença de um radical metila no anel B reduziu significativamente a atividade da galocatequina. Todas as substâncias isoladas mostraram maior atividade do que a vitamina $\mathrm{C}$ e trolox, e estes não mostraram diferença significativa entre si.

Unitermos: Stryphnodendron obovatum. Capacidade antioxidante. Taninos condensados. Radical livre DPPH. Complexo fosfomolibdênio.

\section{INTRODUCTION}

Stryphnodendron obovatum Benth. is a native species of the Brazilian cerrado (savanna), and belongs to the family Leguminosae (Cronquist, 1988). It is a perennial shrub about 3-4 meters in height. Popularly known as "barbatimão", this plant has long been used in the treatment of several diseases and particularly in cases of skin ulcerations, principally as a wound healant and antiseptic. The chemical constituents of members of the genus Stryphnodendron evaluated to date include, in the bark as well as in the leaves or beanlike seeds: sapogenins (Tursch et al., 1963, 1966), galactomannans (Reicher et al., 1993), and tannins (Mello, Petereit, Nahrstedt, 1996a, 1996b, 1999).

Plants containing tannins are used in traditional medicine to treat maladies such as diarrhea, arterial hypertension, rheumatism, bleeding, wounds, and burns, among others (Santos, Mello, 2007). Several kinds of activity in bark extracts from members of the genus Stryphnodendron have been described, such as wound healing, antimicrobial, anti-ulcer, hypotensive, anti-parasite against Leishmania amazonensis (Jorge et al., 1996) and Trypanosoma cruzi (Herzog-Soares et al., 2002), antiviral activity (Felipe et al., 2006), antifungal activity against Candida albicans (Ishida et al., 2006), antinociceptive activity (Melo et al., 2007) as well as antioxidant capacity by the free-radical DPPH method, using thin-layer chromatography (Sanches et al., 2005).

The objective of the present study was to evaluate the antioxidant capacity of extracts and isolated condensed tannins from the stem bark of $S$. obovatum.

\section{MATERIAL AND METHODS}

\section{General experimental procedures}

For the chromatography, we used columns containing Sephadex ${ }^{\circledR}$ LH-20; $F_{254}\left(\right.$ Merck $\left.^{\circledR}\right)$ silica-gel chromatography plates; high-speed countercurrent chromatograph, equipped with a Teflon column $130 \mathrm{~m}$ x $1.6 \mathrm{~mm}$, capacity $285 \mathrm{~mL}$, sample injector P.C. Inc. Ito, with a $10 \mathrm{ml}$ loop and $1 \mathrm{~mL} \cdot \mathrm{min}^{-1}$ flow; ISCO Model 328 fraction collector; and a Pharmacia Biotech FRAC-200 fraction collector.

For the NMR spectra of $1 \mathrm{D}\left({ }^{1} \mathrm{H},{ }^{13} \mathrm{C}\right), 2 \mathrm{D}\left({ }^{1} \mathrm{H} /{ }^{1} \mathrm{H}\right.$, COSY, HMBC, HMQC) we used a Mercury Plus-300BB Varian spectrometer, $300 \mathrm{MHz}$, using $\mathrm{CDCl}_{3}$ and TMS as an internal reference. The mass spectra (EM) were measured in an ESI-MS Quatro LCZ Micromass mass spectrometer (Manchester, UK). Circular dichroism was measured in a Jasco J-600 spectropolarimeter in $\mathrm{MeOH}$ $\left(\mathrm{ChromAr}^{\circledR}, \mathrm{Merck}^{\circledR}\right)$. To obtain the crude extract, we used an Ultra-turrax ${ }^{\circledR}$ UTC115KT; a Büchi R-114, R-153 rotavapor; a Christ Alpha 1-2 lyophilizer; and a Tigre model ASN-5 hammer mill for pulverizing the plant drug.

\section{Plant material}

The samples of stem bark from Stryphnodendron obovatum Benth. were collected in February 2001 and 2003 (under authorization \#42.697/2002), on the grounds of the Instituto Florestal of Assis, state of São Paulo (22 35'20.8'S; 50²4'18.7'W; $546 \mathrm{~m}$ altitude), Brazil. The voucher specimens were deposited under numbers HUM 8137 and 9972 at the Herbarium of the State University of Maringá, Paraná. Prof. Dr. Cássia Mônica Sakuragui confirmed the plants identification.

\section{Extraction and isolation}

The dried bark was pulverized in a hammer mill (Tigre ASN-5) to give a mean particle size of $300 \mathrm{~nm}$. The crude extract was taken at $10 \%(\mathrm{~m} / \mathrm{v})$, beginning with $1000 \mathrm{~g}$ of the plant drug with the extractor liquid acetone:water (7:3; $\mathrm{v} / \mathrm{v})($ crude extract $=\mathrm{CE})$ in an Ultra-turrax for $20 \mathrm{~min}$ (Cork, Krockenberger, 1991). Next, the extract was vacuum-filtered, concentrated in a rotavapor under reduced pressure and lyophilized, for a yield of $31.38 \%$ (313.77 g). $200 \mathrm{~g}$ of the lyophilized extract was partitioned with ethyl acetate (Porter, 1989; Mello, Petereit, Nahrstedt, 1996a, 1996b, 1999), resulting in an ethyl-acetate fraction $(30.28 \mathrm{~g}$; EtOAc) and an aqueous fraction (153.82 $\mathrm{g}$; AQ). The ethyl-acetate fraction (20 g) was column-chromatographed, yielding 24 subfractions. Fractions 6, 7, 8 and 9 were submitted to high-speed counter-current chromatography (ethyl acetate: $n$-propanol: water; $140: 8: 80 ; \mathrm{v} / \mathrm{v}$ ), flow rate $1.0 \mathrm{~mL} \cdot \mathrm{min}^{-1}$, using the upper 
phase as the mobile phase (Mello, Petereit, Nahrstedt, 1996a, 1996b, 1999). Column chromatography was also employed, using different proportions of ethanol $(1,2,3,4,5$, and $8 \%)$ as the mobile phase, collecting $3 \mathrm{~mL} \cdot \mathrm{min}^{-1}$ in each test tube. The fractions were separated by thin-layer chromatography (mobile phase: ethyl acetate: formic acid: water; 90:5:5; spray reagent: $1 \% \mathrm{FeCl}_{3}$ in $\mathrm{EtOH}$ ) resulting in compounds 1, 2, 3, 4 and 5. Fraction 10 was acetylated [with acetic anhydride and pyridine(Mello, Petereit, Nahrstedt, 1996a, 1996b, 1999)] and then purified in preparative thin-layer chromatography (toluene:acetone; $7: 3 \mathrm{v} / \mathrm{v}$ ), resulting in compounds $\mathbf{6 a}, 7 \mathbf{a}$, 8a and 9a.

\section{Antioxidant activity in vitro}

The ethyl-acetate fraction, the aqueous fraction, the crude extract and the isolated compounds were analyzed by the method of scavenging of the DPPH free radical (Amarowicz et al., 2004), and the extracts were evaluated by the method of reduction of the phosphomolybdenum complex, to demonstrate the total antioxidant capacity (May, 1999).

The method of scavenging of the DPPH (2,2-diphenyl-1-picrilhydrazil) radical was read in a spectrophotometer at $517 \mathrm{~nm}$, and the results were expressed as $\mathrm{IC}_{50}$ (quantity of antioxidant necessary to reduce by $50 \%$ the initial free-radical DPPH concentration). The calculations were done by linear regression.

The results from the phosphomolybdenum-complex reduction method were expressed as RAC (relative antioxidant capacity). Absorbance was read at $695 \mathrm{~nm}$. The antioxidant capacity of the extracts was expressed in relation to ascorbic acid, used as a standard, with the reference antioxidant activity considered as $1(100 \%)$.

\section{Statistical analysis}

The results are presented as mean \pm standard deviation of the mean. The experiments were performed in triplicate. The statistical analysis was done by nonparametric Anova, Tukey's method, with the program GraphPad Prism 3.0 ${ }^{\circledR}$.

\section{RESULTS AND DISCUSSION}

The crude extract (CE), ethyl-acetate (EtOAc) and aqueous (AQ) fractions from the stem bark of $S$. obovatum were evaluated for their free-radical scavenging capacity by means of the stable free-radical DPPH, and compared to the standard vitamin $\mathrm{C}$ (Figure 1).

The CE and EtOAc extracts of S. obovatum showed

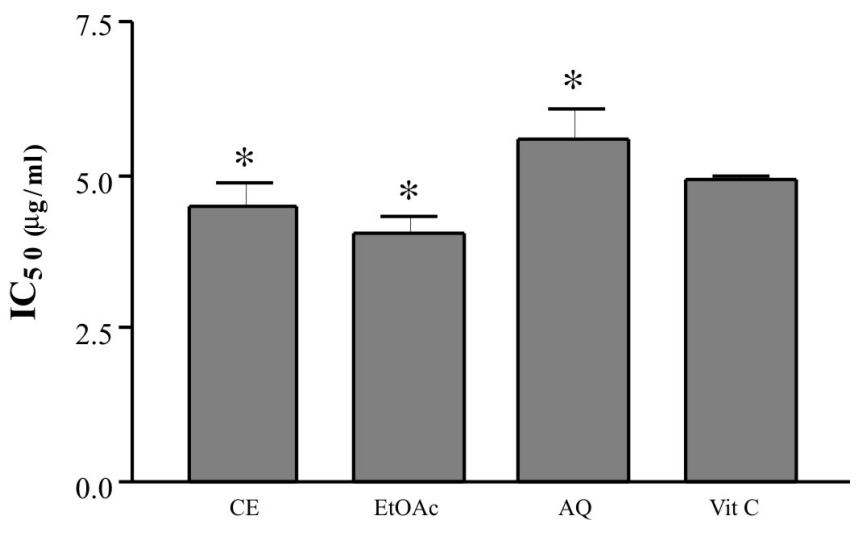

FIGURE 1 - Evaluation of antioxidant capacity by the DPPH free-radical method: $\mathrm{CE}\left(\mathrm{IC}_{50} 4.52 \mu \mathrm{g} / \mathrm{ml} \pm 0.16\right.$; $\left.\mathrm{RSD} \%=3.54\right)$; EtOAc fraction $\left(\mathrm{IC}_{50} 4.04 \mu \mathrm{g} / \mathrm{mL} \pm 0.13 ; \mathrm{RSD} \%=3.22\right)$; AQ fraction $\left(\mathrm{IC}_{50} 5.58 \mu \mathrm{g} / \mathrm{ml} \pm 0.22 ; \mathrm{RSD} \%=3.94\right)$; vitamin $\mathrm{C}$ $\left(\mathrm{IC}_{50} 4.93 \mu \mathrm{g} / \mathrm{mL} \pm 0.05 ; \mathrm{RSD} \%=1.07\right)$. *Significant difference $(P<0.005)$ from vitamin $\mathrm{C}$.

significant antioxidant capacity compared to vitamin C $(P<0.005)$. The EtOAc fraction had a greater capacity to reduce the DPPH radical than did the CE and AQ. This probably occurred because the tannin content in this fraction $[55.01 \pm 0.36 \%(\mathrm{CV}=0.65 \%)]$ was higher than in the CE $[36.58 \pm 0.35 \%(\mathrm{CV}=0.98 \%]$ or AQ $[29.54 \pm 0.23 \%$ $\mathrm{CV}=0.58 \%)]$ fractions. In certain species, such as Vitis vinifera, the extract that demonstrated the highest DPPH radical-scavenging activity, was also the richest in polyphenols (condensed tannins) (Guendez et al., 2005). In Geranium niveum $\left(\mathrm{IC}_{50} 7.3 \mu \mathrm{g}\right.$ ) the methanolic extract showed higher antiradical activity by DPPH than dimeric (geranin A) or trimeric (geranin D) compounds (Maldonado et al., 2005), and in Prunus domestica the semipurified fraction containing proanthocyanidin oligomer $\left(\mathrm{IC}_{50} 2.1 \mu \mathrm{M}\right)$ displayed more potent activity than chlorogenic acid, epicatechin and ascorbic acid (Kimura et al., 2008). These findings showed that the extracts gave better results than did monomeric, dimeric or trimeric condensed tannins.

The results of the evaluation of the total antioxidant capacity by the method of reduction of the phosphomolybdenum complex are shown in Figure 2.

Figure 2 shows the values found for the antioxidant capacity of the crude extract, the ethyl-acetate fraction, and the aqueous fraction in relation to vitamin $\mathrm{C}(200 \mu \mathrm{g} \mathrm{mL})$, referenced as 1.0. Vitamin $\mathrm{C}$ is recognized for its antioxidant power, which is assigned the value of unity (May, 1999), and is frequently used as a reference in this test (Prietto, Pineda, Aguilar, 1999). The ethyl-acetate fraction showed the highest potential to reduce the phosphomolybdenum complex $(\mathrm{RAC}=0.9537 \pm 0.067$; $\mathrm{RSD} \%=7.02)$, 


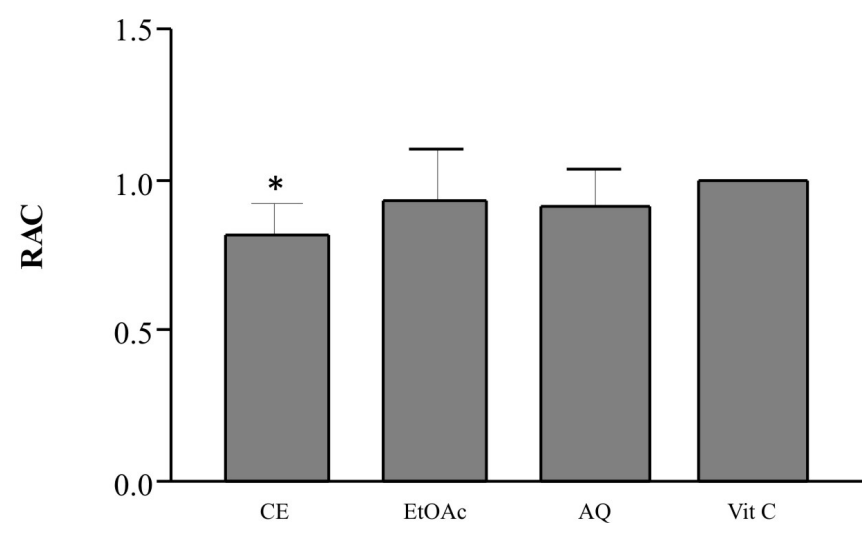

FIGURE 2 - Evaluation of total antioxidant capacity by the phosphomolybdenum reduction method: CE $(\mathrm{RAC}=0.8242 \pm 0.0445 ; \mathrm{RSD} \%=5.39 \%)$; vitamin $\mathrm{C}(\mathrm{RAC}=1.0)$; EtOAc fraction $(\mathrm{RAC}=0.9537 \pm 0.067 ; \mathrm{RSD} \%=7.02)$; $\mathrm{AQ}$ fraction $(\mathrm{RAC}=0.9275 \pm 0.0498 ; \mathrm{RSD} \%=5.37 \%)$. * Significant difference $(P<0.005)$ from vitamin $\mathrm{C}$.

followed by the aqueous fraction ( $\mathrm{RAC}=0.9275 \pm 0.0498$; $\mathrm{RSD} \%=5.37)$ and the crude extract $(\mathrm{RAC}=0.8242 \pm 0.0445$; $\mathrm{RSD} \%=5.39)$. Statistical analysis indicated a significant difference between vitamin C (1.0) compared to the crude extract $(P<0.005)$, demonstrating that $\mathrm{CE}$ has no capacity to reduce the phosphomolybdenum complex.

Obviously it is not possible to compare the different antioxidant methods, but the EtOAc fraction did show a compatible antioxidant capacity in the two methods evaluated, whereas the $\mathrm{AQ}$ fraction differed in respect to the $\mathrm{CE}$.

It is evident that the interaction of a potential antioxidant with the DPPH radical depends on its structural conformation. Certain compounds react very rapidly with the DPPH radical, reducing a number of DPPH molecules corresponding to the number of available hydroxyl groups (Antolovich et al., 2002).

The phosphomolybdenum complex method is based on the reducing potential of the hydroxyl group of the 6-hydroxychroman ring, which is shared by all flavan-3ols (condensed tannins) and flavonoids. Thus, this method employs the reduction of $\mathrm{Mo}(\mathrm{VI})$ to $\mathrm{Mo}(\mathrm{V})$ by the sample analyte (Prieto, Pineda, Aguilar, 1999).

Therefore, it is expected that the free-radical scavenging activity of flavonoids, tannins and other phenols is mostly due to their aromatic hydroxyl groups, which confer great stability on the phenolic radical as soon as it is formed, after donation of one hydrogen radical to DPPH. According to our results, one can conclude that the ethyl-acetate fraction, in both methods, showed the greatest capacity to scavenge free radicals. As can be observed, the chemical evaluation of the ethyl-acetate fraction indicated the presence of a large quantity of poly- phenolic compounds (condensed tannins, see chemical considerations below).

Figure 3 shows the values obtained by the in vitro DPPH free-radical method for the isolated compounds, which were $\mathrm{IC}_{50}(\mu \mathrm{M}): \mathrm{GA}=8.89 \pm 0.09\left(\mathrm{RSD}^{2}=1.04\right)$; $\mathrm{PHB}=10.12 \pm 0.23(\mathrm{RSD} \%=2.54) ; \mathrm{GC}=16.46 \pm 0.13$ $(\mathrm{RSD} \%=0.77) ; \mathrm{EPG}=13.20 \pm 0.11(\mathrm{RSD} \%=0.84)$; $\mathrm{MGC}=21.00 \pm 0.12(\mathrm{RSD} \%=0.60) ; \mathrm{EPEP}=6.89 \pm 0.13$ $(\mathrm{RSD} \%=1.94) ; \mathrm{EPGC}=4.91 \pm 0.03(\mathrm{RSD} \%=0.66)$; $\mathrm{ROGC}=7.78 \pm 0.10(\mathrm{RSD} \%=1.34)$ and $\mathrm{ROEP}=6.20 \pm 0.07$ $(\mathrm{RSD} \%=1.16)$. Vitamin $\mathrm{C}$ and trolox showed $\mathrm{IC}_{50}(\mu \mathrm{M})$ of $30.11 \pm 1.31(\mathrm{RSD} \%=4.36)$ and $30.10 \pm 0.48(\mathrm{RSD} \%=1.59)$, respectively.

These data demonstrate unequivocally that dimeric condensed tannins show significantly different free-radical scavenging activity from the monomers of flavan-3-ols (gallocatechin and epigallocatechin). There was a significant difference between gallocatechin and epigallocatechin, which may be related to the stereochemistry of the compounds. Note the presence of a methoxyl group at position 4' of gallocatechin, which reduced its free-radical scavenging activity compared to the non-substituted compound. There was a significant difference between dimers with a hydroxyl group at position 5 (prodelphinidins) and those without a hydroxyl group at this position (prorobinetinidins). Similarly to the monomers, the dimers showed the same characteristic in relation to the stereochemistry. There was a statistical difference among all the dimers; however, the differences were smaller between EPEP and ROEP, and between EPEP and ROGC, whereas for all other combinations the differences were greater (data not shown). One can deduce that in substances with relative stereochemistry of type 2,3-cis, 3,4-trans and 2,3-trans, 3,4-cis in the "upper" unit, since the "lower" unit shows the 2,3-cis configuration, the statistical differences are smaller, showing some similarity in antioxidant activity; and this similarity is therefore related to the stereochemistry of the substances. There was no significant difference between vitamin $\mathrm{C}$ and trolox.

This confirmed the observation of van Acker et al. (1996) that compounds with groups of the pyrogallol type (trihydroxylated) possess greater activity than compounds with groups of the catechol type (dihydroxylated).

However, this is the first report to compare antioxidant activity between proanthocyanidins with or without a hydroxyl group at A ring position 5. For this evaluation there are no currently available parameters for comparison, because 5-deoxyproanthocyanidins have been isolated from only a few plant species, including: Stryphnodendron spp., Acacia mearnsii, A. mollissima and Schinopsis spp. (Roux, Evelyn, 1960; Roux, Paulus, 1961; Mello, Petereit, 


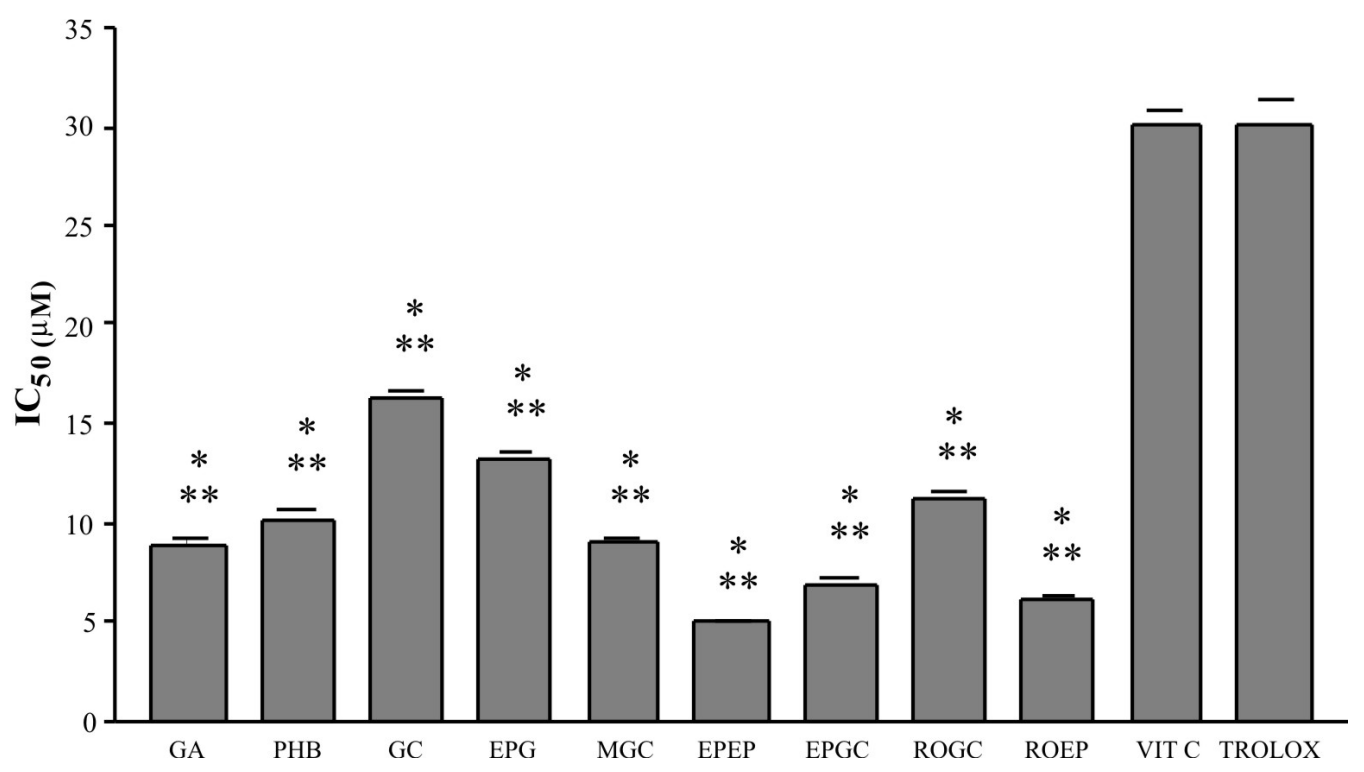

FIGURE 3 - Evaluation of antioxidant activity by the DPPH free-radical method. GA= Gallic acid; PHB= $p$-hydroxy-benzoic acid; $\mathrm{GC}=$ gallocatechin; $\mathrm{EPG}=$ epigallocatechin; $\mathrm{MGC}=4$ '- $O$-methylgallocatechin; $\mathrm{EPEP}=$ epigallocatechin- $(4 \beta \rightarrow 8)$-epigallocatechin; $\mathrm{EPGC}=$ epigallocatechin- $(4 \beta \rightarrow 8)$-gallocatechin; $\mathrm{ROGC}=$ robinetinidol- $(4 \alpha \rightarrow 8)$-gallocatechin; $\mathrm{ROEP}=\mathrm{robinetinidol}-(4 \beta \rightarrow 8)-$ epigallocatechin *Significant difference $(P<0.001)$ from vitamin . ** Significant difference $(P<0.001)$ from trolox.

Nahrstedt, 1996a, 1996b and 1999). A similar situation was obtained with 4'-O-methylgallocatechin, which has been isolated from only Panda oleosa and Stryphnodendron spp. (Garcia et al., 1993; Mello, Petereit, Nahrstedt, 1996a).

The EtOAc fraction obtained from the CE of stem bark of Stryphnodendron obovatum Benth. was chromatographed on a Sephadex LH-20 column, and fractions 6, 7,8 and 9 were further purified by high-speed countercurrent chromatography (HSCCC) to obtain compounds 1-5. Fraction 10 resulted after HSCCC and derivation by acetylation in compounds 6-9. The structural identification of all biflavonoid prodelphinidins and prorobinetinidins (6-9) was established by the physical properties [ ${ }^{1} \mathrm{H}$ NMR, circular dichroism (CD), and DCI-mass spectrometry] of the corresponding peracetate derivatives.

Compounds 1, 2, 3, 4 and 5 were identified as gallic acid ( $9 \mathrm{mg} ; 0.0027 \%$ of the CE), $p$-hydroxybenzoic acid (2 $\mathrm{mg} ; 0.0006 \%$ of the CE), gallocatechin (106 mg; $0.032 \%$ of the CE), epigallocatechin ( $172 \mathrm{mg} ; 0.052 \%$ of the CE) and 4'-O-methylgallocatechin (16 mg; $0.0048 \%$ of the $\mathrm{CE})$, respectively, by comparing the NMR and MS data with authentic samples, and by comparison with the literature (Figure 4). These compounds have also been reported from other plants with antioxidant activity, and from other species of Stryphnodendron (Garcia et al., 1993; Mello, Petereit, Nahrstedt, 1996a, 1996b).

Compounds $\mathbf{6 a}$ and $7 \mathbf{a}$ derived chemically (by acetylation) were identified as epigallocatechin-( $4 \beta \rightarrow 8)$ - epigallocatechin (12 mg; 0.0036\%) and epigallocatechin$(4 \beta \rightarrow 8)$-gallocatechin ( $14 \mathrm{mg} ; 0.0042 \%$ of the $\mathrm{CE}$ ), from the data from NMR and MS compared to the authentic sample, and also with the literature (Figure 5). Compound 6a showed in the aromatic region two singlets corresponding to two protons each, referring to rings $\mathrm{E}$ and $\mathrm{B}$ at $\delta$ 6.89 and $\delta 7.22$ (H-2' and H-6'), respectively, showing the pattern of pyrogallol hydroxylation. The heterocyclic coupling constants $(J \leq 2.0 \mathrm{~Hz})$ confirmed the relative 2,3-cis configuration of the "upper" and "lower" constituent units (Weinges et al., 1969). The chemical shifts for H-2(F) $(\delta$<smiles>O=C(O)c1ccc(O)c(O)c1</smiles>

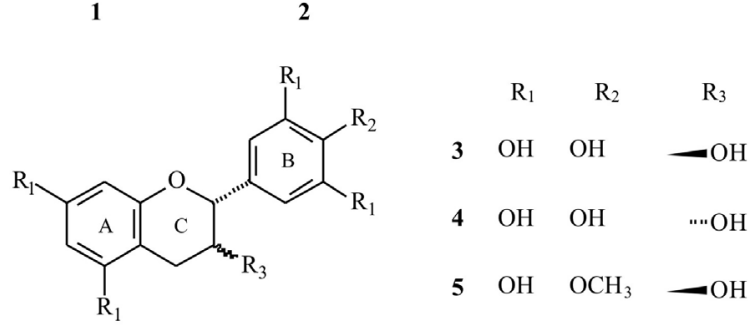

FIGURE 4 - Isolated compounds 1 (gallic acid), 2 ( $p$-hydroxybenzoic acid), $\mathbf{3}$ (gallocatechin), 4 (epigallocatechin) and 5 (4'-O-methylgallocatechin) from the ethyl-acetate fraction of Stryphnodendron obovatum. 
4.50), H-6(A) ( $\delta 6.06)$ and $\mathrm{H}-8(\mathrm{~A})(\delta 6.25)$, in conjunction with the dominance of one conformer, indicated a $(4 \rightarrow 8)$ interflavonoid linkage (Hemingway, Foo, Porter, 1982; Kolodziej, 1992; Danne, Petereit, Nahrstedt, 1994; Mello, Petereit, Nahrstedt, 1996a, 1996b, 1999). The $4 \beta$ linkage of the flavanyl substituent and hence the $4 R$ absolute configuration of $\mathbf{6 a}$ was confirmed by a positive Cotton effect in the CD spectrum at 220-240 nm (Botha, Ferreira, Roux, 1978a; Barret et al., 1979; Botha et al., 1981a). Compound 6 was first identified in Cistus salvifolius L. (Cistaceae) (Danne, Petereit, Nahrstedt, 1994).

Compound 7a showed similarities to compound 6a, differing only in the coupling constant of the protons of the $\mathrm{F}$ heterocyclic ring ( $\mathrm{H}-2$ and $\mathrm{H}-3)$, with a value of $J_{2,3}=9.9 \mathrm{~Hz}$. Thus, a relative 2,3-trans configuration for the "lower" unit was confirmed. The mass spectrum showed the same pattern of fragmentation, with the pseudo-molecular ion (positive mode) $[\mathrm{M}+18]^{+} \mathrm{m} / z 1133$ for compounds $6 \mathbf{a}$ and $7 \mathbf{a}$. The $4 \beta$ linkage of the flavanyl substituent and hence the $4 R$ absolute configuration of $7 \mathbf{a}$ was confirmed by a positive Cotton effect in the CD spectrum at 220-240 nm (Botha, Ferreira, Roux, 1978a; Barret et al., 1979; Botha et al., 1981a). These compounds were previously isolated and characterized in Stryphnodendron adstringens (Mart.) Coville (Mello, Petereit, Nahrstedt, 1996a, 1996b, 1999).
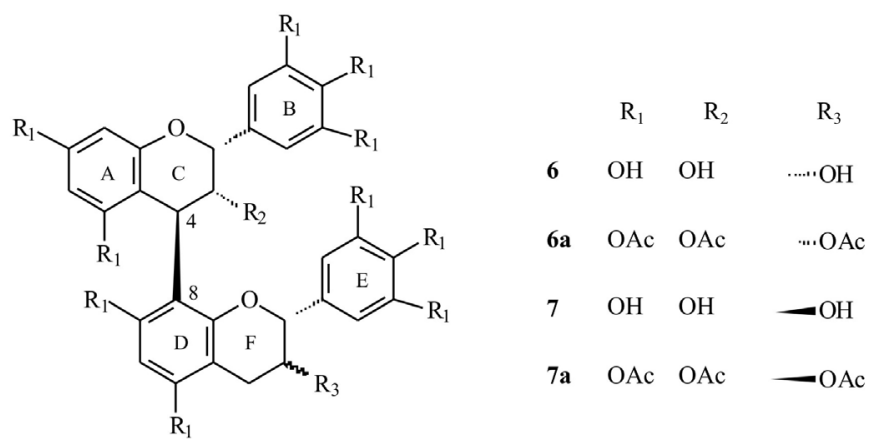

FIGURE 5 - Isolated compounds 6 [epigallocatechin$(4 \beta \rightarrow 8)$-epigallocatechin] and 7 [epigallocatechin$(4 \beta \rightarrow 8)$-gallocatechin] from the ethyl-acetate fraction of Stryphnodendron obovatum.

Peracetate compounds 8a and 9a showed similarities with the corresponding prodelphinidins, except for the Aring region and the analyses of the chemical shifts of the heterocyclic $\mathrm{C}$-ring protons. Therefore, these compounds were identified as robinetinidol- $(4 \alpha \rightarrow 8)$-gallocatechin $(2 \mathrm{mg} ; 0.0006 \%$ of the CE) and robinetinidol- $(4 \beta \rightarrow 8)$ epigallocatechin $(22.5 \mathrm{mg} ; 0.0068 \%$ of the $\mathrm{CE})$ through NMR (1D and 2D), DCI-MS, and CD with authentic samples and in comparison with literature. The ${ }^{1} \mathrm{H}$ NMR data for compounds 8a and 9a are seen in Tables I and II.
TABLE I - NMR spectral data for acetylated compound $\mathbf{8} \mathbf{a}^{\mathrm{a}}$

\begin{tabular}{lccc}
\hline Position & $\delta_{\mathrm{H}}(\mathrm{ppm})^{\mathrm{b}}$ & $J(\mathrm{~Hz})$ & Literature $\delta_{\mathrm{H}}^{\mathrm{b} *}$ \\
\hline $4 \mathrm{ax}(\mathrm{F})$ & $2.66 \mathrm{~m}$ & 2.66 \\
4eq (F) & $2.98 \mathrm{dd}$ & ${ }^{2} J_{4 \text { eq-4ax (F) }}=16.7$ \\
& & ${ }^{3} J_{4 \mathrm{eq}-3(\mathrm{~F})}=5.9$ & 2.99 \\
$4(\mathrm{C})$ & $4.51 \mathrm{~d}$ & ${ }^{3} J_{4-3(\mathrm{C})}=9.8$ & 4.51 \\
2 (C) & $4.89 \mathrm{~d}$ & ${ }^{3} J_{2-3(\mathrm{C})}=9.6$ & 4.90 \\
3 (F) & $4.84-4.87 \mathrm{~m}$ & & $4.80-4.87$ \\
2 (F) & $5.03 \mathrm{~d}$ & ${ }^{3} J_{2-3(\mathrm{~F})}=8.6$ & 5.04 \\
$3(\mathrm{C})$ & $5.78 \mathrm{t}$ & $\Sigma=19.5$ & 5.79 \\
2'/6' (E); & $6.65 \mathrm{~m}$ & & 6.65 \\
6/8 (A); 6 (D) & & & \\
5 (A) & $6.88 \mathrm{~d}$ & ${ }^{3} J_{5-6(\mathrm{~A})}=8.4$ & 6.89 \\
2'/6' (B) & $6.95 \mathrm{~s}$ & & 6.97 \\
\hline
\end{tabular}

a $300 \mathrm{MHz}$ for ${ }^{1} \mathrm{H}, \mathrm{CDCl}_{3}$; ${ }^{\text {b }} \delta$ (ppm), multiplicities; *Mello, Petereit, Nahrstedt (1996a)

TABLE II - NMR spectral data for acetylated compound $9 \mathrm{a}^{\mathrm{a}}$

\begin{tabular}{lccc}
\hline Position & $\delta_{\mathrm{H}}(\mathrm{ppm})^{\mathrm{b}}$ & $J(\mathrm{~Hz})$ & Literature $\delta_{\mathrm{H}}{ }^{\mathrm{b} *}$ \\
\hline $4 \mathrm{ax} / 4 \mathrm{eq}(\mathrm{F})$ & $2.84-2.91 \mathrm{~m}$ & & $2.89-2.98$ \\
$4(\mathrm{C})$ & $4.47 \mathrm{~d}$ & ${ }^{3} J_{3-4(\mathrm{C})}=5.4$ & 4.49 \\
$2(\mathrm{C})$ & $5.48 \mathrm{~d}$ & ${ }^{3} J_{2-3(\mathrm{C})}=7.8$ & 5.5 \\
$3(\mathrm{~F}) / 3(\mathrm{C})$ & $5.27-5.42 \mathrm{~m}$ & & $5.28-5.39$ \\
$2(\mathrm{~F})$ & $4.42 \mathrm{~s}$ & & 4.45 \\
$8(\mathrm{~A})$ & $6.26 \mathrm{~d}$ & ${ }^{3} J_{8-6(\mathrm{~A})}=2.4$ & 6.29 \\
$6(\mathrm{~A})$ & $6.44 \mathrm{dd}$ & ${ }^{3} J_{6-8(\mathrm{~A})}=2.3$ & \\
& & ${ }^{3} J_{4-3(\mathrm{C})}=8.6$ & 6.47 \\
$2^{\prime} / 6 '(\mathrm{E})$ & $6.78 \mathrm{~s}$ & & 6.78 \\
$6(\mathrm{D})$ & $6.64 \mathrm{~s}$ & & 6.66 \\
$5(\mathrm{~A})$ & $6.86 \mathrm{~d}$ & ${ }^{3} J_{5-6(\mathrm{~A})}=6.6$ & 6.86 \\
2'/6' (B) & $7.12 \mathrm{~s}$ & & 7.15 \\
\hline
\end{tabular}

${ }^{\mathrm{a}} 300 \mathrm{MHz}$ for ${ }^{1} \mathrm{H}, \mathrm{CDCl}_{3} ;{ }^{\mathrm{b}} \delta$ (ppm), multiplicities; * Mello, Petereit, Nahrstedt (1996a)

The peracetate derivative (8a) of compound $\mathbf{8}$ (Figure 6) produced a $[\mathrm{M}+18]^{+}$peak at $\mathrm{m} / z 1074$ in the DCI-mass spectrum. The ${ }^{1} \mathrm{H}$ NMR spectrum of $\mathbf{8 a}$ had the characteristic spin system of an all-trans dimeric prorobinetinidin, as evidenced by the coupling constants of the heterocyclic protons $\left(J_{2,3(\mathrm{C})}=9.6 \mathrm{~Hz} ; J_{3,4(\mathrm{C})}=9.8 \mathrm{~Hz} ; J_{2,3(\mathrm{~F})}=8.6 \mathrm{~Hz}\right)$, an aromatic AMX spin system and two two-proton singlets at $\delta 6.97$ and 6.65 , indicating the presence of pyrogalloltype B- and E-rings, respectively. Determination of the "upper" 5-deoxyflavan-3-ol unit was facilitated by the long-range coupling between $\mathrm{H}-5(\mathrm{~A})(\delta 6.89)$ and $\mathrm{H}-4(\mathrm{C})$ 
( $\delta$ 4.51) ('W'-coupling) from a ${ }^{1} \mathrm{H}-{ }^{1} \mathrm{H}$ COSY experiment. The dominance of one rotamer (Fletcher et al., 1977), the chemical shift of H-3(C) $(\delta 5.79 ; \mathrm{t}, \Sigma J=19.5 \mathrm{~Hz})$, the chemical shift of the B-ring protons and the high-amplitude negative Cotton effect in the 220-240 nm region of the $C D$ spectrum of $8 \mathbf{a}$, all confirmed a $(4 \beta \rightarrow 8)$ linkage and, thus, a $4 S$ absolute configuration. Consequently, 8 was characterized as robinetinidol- $(4 \beta \rightarrow 8)$-gallocatechin, previously reported as a prominent metabolite from Acacia mearnsii (Drewes et al., 1966b; Botha, Ferreira, Roux, 1978b; Botha et al., 1981b; Viviers et al., 1983) and also present in S. adstringens (Mello, Petereit, Nahrstedt, 1996a, 1996b, 1999 ) and in S. polyphyllum Mart. (Lopes, 2003). This is the first time that this compound has been reported for $S$. obovatum, which gives a preliminary indication of a close chemotaxonomic relationship between the species.

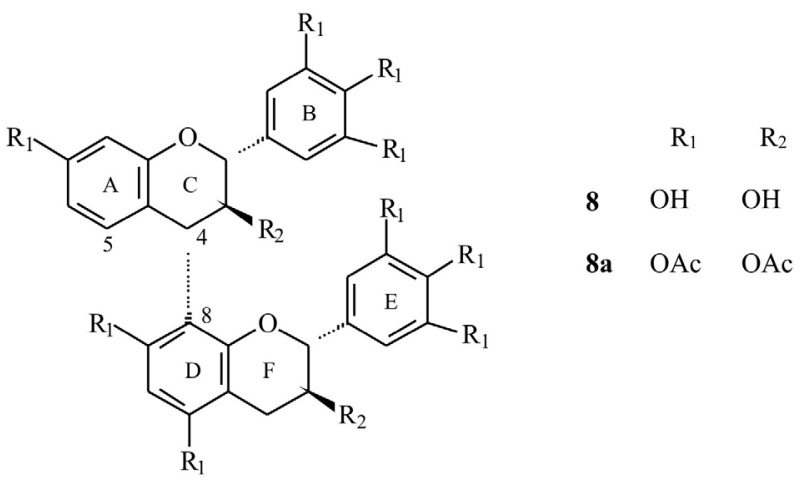

FIGURE 6 - Isolated compound 8 from the ethyl-acetate fraction of Stryphnodendron obovatum.

The ${ }^{1} \mathrm{H}$ NMR spectrum of compound 9a showed the aromatic substitution pattern and also the 5-deoxyproanthocyanidin character, as evident from an AMX spin system $(\delta 6.26-6.86)$, a residual D-ring proton at $\delta 6.66$ and two two-proton singlets at $\delta 6.78$ and 7.12. As in the prodelphinidin compounds, the signals were assigned to the equivalent E- and B-ring protons, respectively, with the aid of a ${ }^{1} \mathrm{H}-{ }^{1} \mathrm{H}$ COSY experiment with the $2-\mathrm{H}(\mathrm{C})$ and $2-\mathrm{H}(\mathrm{F})$ resonances as reference signals. The "upper" 5-deoxyflavan-3-ol unit was determined as for compound 8a, by the long-range coupling between $\mathrm{H}-5(\mathrm{~A})(\delta 6.86)$ and $\mathrm{H}-4(\mathrm{C})(\delta 4.47)$ ('W'-coupling) from a $2 \mathrm{D}$ NMR $\left({ }^{1} \mathrm{H}-\right.$ ${ }^{1} \mathrm{H}$ COSY). The coupling constants of the C-ring protons $\left(J_{2,3}=7.8 \mathrm{~Hz} ; J_{3,4}=5.4 \mathrm{~Hz}\right)$ confirmed the 2,3-trans-3,4-cis relative configuration, whereas the 2,3-cis configuration of the "lower" unit was evident from the small coupling constants of the heterocyclic protons $\left(J_{2,3}<2.0 \mathrm{~Hz}\right)$. The chemical shift and the splitting pattern of proton $3(\mathrm{C})$ are useful for the differentiation of dimers with 2,3-trans-3,4- cis and 2,3-trans-3,4-trans configuration, only in the case of methoxyacetylated 5-deoxyproanthocyanidins (Fletcher et al., 1977). The chemical shift of the H-6(A) $(\delta 6.44), \mathrm{H}-$ $8(\mathrm{~A})(\delta 6.26)$ and $\mathrm{H}-2(\mathrm{~F})(\delta 4.42)$, and the clear dominance of one rotamer indicate the $(4 \rightarrow 8)$ interflavanyl linkage. The chemical shift of the proton $3(\mathrm{C})$ between $\delta 5.27-5.42$ was similar to those of methoxyacetylated biflavonoids of corresponding configuration, and suggest a 2,3-trans-3,4cis stereochemistry. The $2 R, 3 S, 4 R$ absolute configuration was determined from the high-amplitude positive Cotton effect in the 220-240 $\mathrm{nm}$ region of the CD spectrum of 9 a. Compound 9 was determined as robinetinidol- $(4 \beta \rightarrow 8)$ epigallocatechin (Figure 7), which was previously isolated from S. adstringens (Mello, Petereit, Nahrstedt, 1996a, 1996b, 1999); this is the first time that the compound, has been reported for $S$. obovatum.

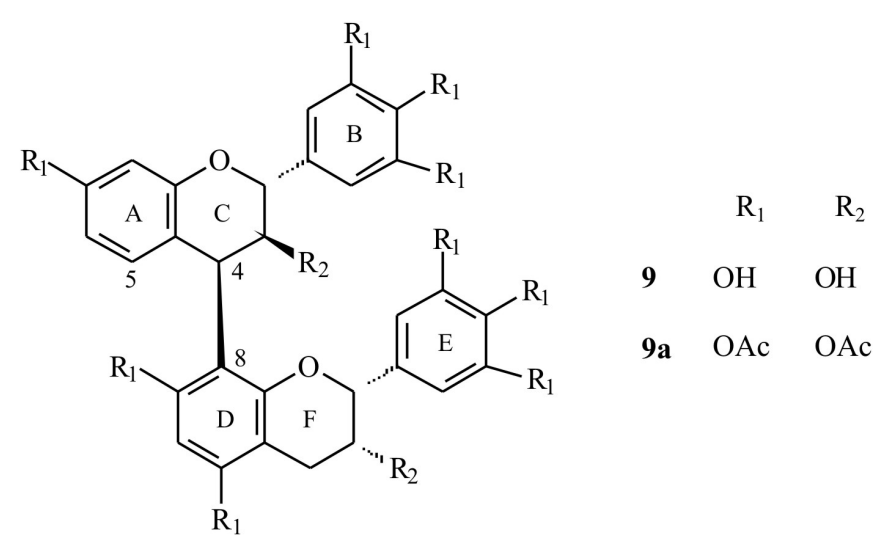

FIGURE 7 - Isolated compound 9 from the ethyl-acetate fraction of Stryphnodendron obovatum.

\section{ACKNOWLEDGEMENTS}

We thank CNPq and CAPES for financial support, and the Instituto Florestal de São Paulo for permission to collect the plant material. The valuable observations of two anonymous reviewers contributed significantly to improvements in the manuscript.

\section{REFERENCES}

AMAROWICZ, R.; PEGG, R. B.; RAHIMI-MOGHADDAM, P.; BARL, B., WEIL, J. A. Free-radical scavenging capacity and antioxidant activity of selected plant species from the Canadian prairies. Food Chem., v.84, p.551-562, 2004. 
BARRETT, M. W.; KLINE, W.; SCOPES, P. M.; FLETCHER, A. C.; PORTER, L. J.; HASLAM, E. Plant proanthocyanidins. Part 6. Chiroptical studies. Part 95. Circular dichroism of procyanidins. J. Chem. Soc. Perkin Trans. I, p.2375-2377, 1979.

BOTHA, J. J.; FERREIRA, D.; ROUX, D. G. Condensed tannins. Circular dichroism method of assessing the absolute configuration at C-4 of 4-arylflavan-3-ols, and stereochemistry of their formation from flavan-3,4-diols. J. Chem. Soc. Perkin Trans. I, p.698-700, 1978a.

BOTHA, J. J.; FERREIRA, D.; ROUX, D. G. Condensed tannins: direct synthesis, structure, and absolute configuration of four biflavonoids from black wattle bark (Mimosa) extract. J. Chem. Soc.Chem. Comm., v.16, p.700-702, 1978b.

BOTHA, J. J.; YOUNG, D. A.; FERREIRA, D.; ROUX, D. G. Synthesis of condensed tannins. Part 1. Stereoselective and stereospecific syntheses of optically pure 4-arylflavan-3-ols, and assessment of their absolute stereochemistry at C-4 by means of circular dichroism. J. Chem. Soc. Perkin Trans. I, p.1213-1219, 1981a.

BOTHA, J. J.; YOUNG, D. A.; FERREIRA, D.; ROUX, D. G. Synthesis of condensed tannins. Part.4 A direct biomimetic approach to [4,6]- and [4-8]- biflavonoids. $J$. Chem. Soc. Perkin Trans. I, p.1235-1245, 1981 b.

CORK, S. J.; KROCKENBERGER, A. K. Methods and pitfalls of extraction condensed tannins and other phenolics from plants: insights from investigations on Eucalyptus leaves. J. Chem. Ecol., v.17, p.123-134, 1991.

CRONQUIST, A. The evolution and classification of flowering plants. 20.ed. New York: The New York Botanical Garden, 1988. p.261.

DANNE, A.; PETEREIT, F.; NAHRSTEDT, A. Flavan-3-ol prodelphinidins and further polyphenols from Cistus salvifolius. Phytochemistry, v.37, p.533-538, 1994.

DREWES, S. E.; ROUX, D. G.; SAAYMAN, H. M.; FEENEY, J.; EGGERS, S. H. The stereochemistry of biflavonols from black wattle bark: Leucorobinetinidin$(+)$-catechin and Leucorobinetinidin-(+)-gallocatechin. J. Chem. Soc. Chem. Comm., v.12, p.370-371, 1966.
FELIPE, A. M. M.; RINCÃO, V. P.; BENATI, F. J.; LINHARES, R. E. C.; GALINA, K. J.; TOLEDO, C. E. M.; LOPES, G. C.; MELLO, J. C. P.; NOZAWA, C. Antiviral effect of Guazuma ulmifolia and Stryphnodendron adstringens on poliovirus and bovine herpesvirus. Biol. Pharm. Bull., v.29, p.1092-1095, 2006.

FLETCHER, A. C.; PORTER, L. J.; HASLAM, E.; GUPTA, R. K. Plant proanthocyanidins. Part 3. Conformational and configurational studies of natural procyanidins. $J$. Chem. Soc. Perkin Trans. I, p.1628-1637, 1977.

GARCIA, J.; MASSOMA, T.; MORIN, C.; MPONDO, T. N.; NYASSÉ, B. 4'-O-methylgallocatechin from Panda oleosa. Phytochemistry, v.32, p.1626-1628, 1993.

GUENDEZ, R.; KALLITHRAKA, S.; MAKRIS, D. P.; KEFALAS, P. Determination of low molecular weight polyphenolic constituents in grape (Vitis vinifera $\mathrm{sp}$.) seed extracts: correlation with antiradical activity. Food Chem., v.89, p.1-9, 2005.

HERZOG-SOARES, J. D. A.; ALVES, R.; ISAC, E.; BEZERRA, J. C.; GOMES, M. H.; SANTOS, S. C.; FERRI, P. H. Atividade tripanocida in vivo de Stryphnodendron adstringens (barbatimão verdadeiro) e Caryocar brasiliensis (pequi). Rev. Bras. Farmacog., v.12, suppl.1, p.1-2, 2002.

HEMINGWAY, R. W.; FOO, L. Y.; PORTER, L. J. Linkage isomerism in trimeric and polymeric 2,3-cis-procyanidins. J. Chem. Soc. Perkin Trans. I, p.1209-1206, 1982.

HIRATA, L. L. Avalição da capacidade antioxidante de extratos de Bauhinia microstachya Macbride, Cesalpiniaceae, em serum. Curitiba, 2004. 96p. [Dissertação de Mestrado. Programa de Pós-Grauação em Ciências Farmacêuticas. Universidade Federal do Paraná].

ISHIDA, K.; MELLO; J. C. P.; CORTEZ, D. A. G.; DIAS FILHO, B. P.; UEDA-NAKAMURA, T.; NAKAMURA, C. V. Influence of tannins from Stryphnodendron adstringens on growth and virulence factors of Candida albicans. J. Antimicrob. Chemother., v.58, p.942-949, 2006.

JORGE, A. S.; SILVEIRA, T. G. V.; ARRAES, S. M. A. A.; MELlO, J. C. P. DE; BERTOLini, D. A.; Anti-leishmanial "barbatimão" [(Stryphnodendron adstringens (Martius) Coville, Mimosaceae)] extract against promastigote forms of Leishmania amazonensis. Mem. Inst. Oswaldo Cruz, v.91, p.1976-1976, 1996. 
KIMURA, Y.; ITO, H.; KAWAJI, M.; IKAMI, T.; HATANO, T.; Characterization and antioxidative properties of oligomeric proanthocyanidin from prunes, dried fruit of Prunus domestica L. Biosci. Biotechnol. Biochem., v.72, p.1615-1618, 2008.

KOLODZIEJ, H. ${ }^{1} \mathrm{H}$ NMR spectral studies of procyanidin derivatives: derivation of diagnostic ${ }^{1} \mathrm{H}$ NMR parameters applicable to the structural elucidation of oligomeric procyanidins. In: HEMINGWAY, R. W.; LAKS, P. E. (Eds.). Plant polyphenols: synthesis, properties, significance. New York: Plenum Press, 1992. p.295-320.

LOPES, G. C. Estudos botânico, físico-químico, químico e biológico de cascas de Stryphnodendron polyphyllum Mart. (Leguminosae). Maringá, 2003. 255p. [Dissertação de Mestrado. Universidade Estadual de Maringá].

MALDONADO, P. D.; RIVERO-CRUZ, I.; MATA, R.; PEDRAZA-CHAVERRÍ, J. Antioxidant activity of A-type proanthocyanidins from Geranium niveum (Geraniaceae). J. Agric. Food Chem., v.53, p.1996-2001, 2005.

MAY, J. M. Is ascorbic acid an antioxidant for the plasma membrane. Faseb J., v.13, p.995-1006, 1999.

MELO, J. O.; ENDO, T. H.; BERSANI-AMADO, L. E.; SVIDZINSKI, A. E.; BARONI, S.; MELLO, J. C. P.; BERSANI-AMADO, C. A. Effect of Stryphnodendron adstringens (barbatimão) bark on animal models of nociception. Rev. Bras. Cienc. Farm., v.43, p.465-469, 2007

MELlo, J. C. P. DE; PETEREIT, F.; NAHRSTEDT, A. Flavan-3-ols and prodelphinidins from Stryphnodendorn adstringens. Phytochemistry, v.41, p.807-813, 1996a.

MELLO, J. C. P. DE; PETEREIT, F.; NAHRSTEDT, A. Prorobinetinidins from Stryphnodendorn adstringens. Phytochemistry, v.42, p.857-862, $1996 \mathrm{~b}$.

MELLO, J. C. P. DE; PETEREIT, F.; NAHRSTEDT, A. A dimeric proanthocyanidin from Stryphnodendron adstringens. Phytochemistry, v.51, p.1105-1107, 1999.

MENEZES, P. R.; SCHWARZ A. E.; SANTOS, C. A. M.; In vitro antioxidant activity of species collected in Paraná. Fitoterapia, v.75, p.398-400, 2004.

PORTER, L. J. Tannins. In: DEY, P. M.; HARBORNE, J. B. (Eds.). Methods in plant biochemistry. London: Academic Press, 1989. p.389-419.
P R I E T T O, P. ; P I N E D A, M . ; A G U I L A R, M . Spectrophotometric quantitations of antioxidant capacity througth the formation of a phosphomolybdenum complex: specific application to the determination of vitamin E. Anal. Biochem., v.269, p.337-341, 1999.

REICHER, F.; LEITNER, S. C. S.; SIERAKOWSKI, M. R.; FONTANA, J. D.; CORREA, J. B. C.; Properties of the seed gum of Stryphnodendron barbatiman (barbatimão). Appl. Biochem. Biotechnol., v.34/45, p.349-357, 1992.

SANCHES, A. C. C.; LOPES, G. C.; NAKAMURA, C. V.; DIAS FILHO; B. P.; MELLO, J. C. P. Antioxidant and antifungal activities of extracts and condensed tannins from Stryphnodendron obovatum Benth. Rev. Bras. Cienc. Farm., v.41, n.1, p.101-107, 2005

SANTOS, S. C.; MELlO, J. C. P. Taninos. In: SIMÕES, C. M. O.; SCHENKEL, E. P.; GOSMANN, G.; MENTZ, L. A.; MELlO, J. C. P. DE; PETROVICK, P. R. Farmacognosia: da planta ao medicamento. 6.ed. Porto Alegre/Florianópolis: Editora da UFRGS/UFSC, 2006. chap. 24, p. 615-656.

TOLEDO, C. E. M.; Estudos anatômico, químico e biológico das cascas de extratos de Stryphnodendron adstringens (Martius) Covile, Leguminosae. Araraquara, 2002. 115p. [Dissertação de Mestrado. Faculdade de Ciências Farmacêuticas. Universidade Estadual Paulista Júlio de Mesquita Filho].

TURSCH, B.; TURSCH, E.; HARRISON, I. T.; BRAZÃO DA SILVA, G. B. C. T. C.; MONTEIRO, H. J.; GILBERT, B.; MORS, W. B.; DJERASSI, C. Terpenoids. LIII. Demonstration of ring conformational changes in triterpenes of the $\beta$-amynn class isolated from Stryphnodendron coriaceum. J. Org. Chem., v.28, p.2390-2394, 1963.

TURSCH, B.; DALOZE, D.; TURSCH, E.; CHIURDOGLU, G.; Triterpenes II(*). Les sapogénines J et L de Stryphnodendron coriaceum. Bull. Soc. Chim. Belge, v.75, p.26-28, 1966.

VAN ACKER, S. A. B. E.; VAN DEN BERG, D.-J.; TROMP, M. N. J. L.; GRIFFIOEN, D. H.; VAN BENNEKOM, W. P.; VAN DER VIJGH, W. J. F.; BAST, A.; Structural aspects of antioxidant activity of flavonoids. Free Rad. Biol. Med., v.20, p.331-342, 1996. 
VIVIERS, P. M.; BOTHA, J. J.; FERREIRA, D.; ROUX, D. G. Synthesis of condensed tannins. Part 7. Angular [4,6: 4,8]-prorobinetinidin triflavonoids from black wattle (Mimosa) bark extract. J. Chem. Soc. Perkin Trans. I, p.17-22, 1983.
WEINGES, K.; BAHR, W.; EBERT, W.; GORITZ, K.; MARX, H. D. Konstitution, Entstehung und Bedeutung der Flavonoid-Gerbstoffe. Fortschritte d. Chem. org. Naturst., v.27, p.158-160, 1969.

Received for publication on $26^{\text {th }}$ March 2008 Accepted for publication on $2^{\text {nd }}$ February 2009 